\title{
COMPRESSIVE STRENGTH AND ANTI RADIATION SHIELDING OF CONCRETE BY PARTIAL REPLACEMENT OF COARSE AGGREGATE BY BARITES AND CEMENT BY SILICA FUME
}

\author{
Harinath Balimidi ${ }^{1}$, Ramesh Sarakadam ${ }^{2}$ \\ ${ }^{1}$ Master of Technology(Structural Engineering), Civil Engineering, VBPG College of Engineering, Telangana, India \\ ${ }^{2}$ Assistant Professor, Civil Engineering, VBPG College of Engineering, Telangana, India
}

\begin{abstract}
An outgrowth of the development of nuclear energy, heavy density concrete is gaining wide spread use as a shielding material to provide protection against radiation hazards. It is also known as radiation shielding concrete. In contrast with conventional concrete weighing around 150 pounds per cubic foot, high-density concretes normally weigh from 200 to 250 pounds per cubic foot. Among the natural aggregates most commonly used are barite, magnetite, limonite, and hematite. The density will depend on the type of aggregate used. The high density concrete protects from harmful radiations X-rays, gamma rays, neutrons. Integral part of this project is to replacement of coarse aggregate with barite and natural sand is used as fine aggregate and $4 \%$ of silica fume are used by weight of cement. Water-cement ratio is to be kept same as that of normal concrete. The properties of HDC Concrete are low thermal expansion, creep deformation and high modulus of elasticity.
\end{abstract}

Keywords: High Density Concrete, Barite, Silica Fume.

\section{INTRODUCTION}

\subsection{Concrete}

Now a days ,Concrete is widely used in the construction ,concrete is composed of cement,aggregates and water bonded together which hardens over time. There are different types of concrete available, the aggregate having large chunks in concrete mix, generally coarse gravel like lime stone, granite with the fine materials such as sand, cement. The range of materials like cement used in the concrete. One of the most important thing is cement is asphalt. Other cementitious materials like fly ash and slag cement, Water is mixed with dry powder,it produces a semi-liquid.

\subsection{High Density Concrete}

HDC have density is greater than $2600 \mathrm{~kg} / \mathrm{m}^{3}$ It is also known as Heavy weight concrete. High density concrete is mainly used where high density is required. It has a better shielding property, so that it can protect harmful radiations like X-rays, gamma rays, and neutrons. High density aggregates are used to achieve heavy weight concrete.

\subsection{Barites}

The Mineral Barytes (or) Barites (BaSo4) are the chief sources of the element barium and its compounds needed by many industries like, Rubber, Textiles, radiation shield, Paper Cardboard, Leather, Oil, Cloth, Linoleum, Plastics, Oil well drilling, paints, marine ballast, ceramics, steel hardening, glass fluxes, specialized plastics, sound proofing, friction material like brakes, clutch pads, Chemicals, Medicine and for glazing in Ceramic Industry. Barites Occurs as Crystals and in massive form with snow white, white, grey and buff colors. The Mineral is distinguished by its high specific gravity (4.3 to 4.5 ). The Mineral is quite brittle and can easily powdered. Andhra Pradesh is endowed with single largest barites deposit in Mangampet - Kadapa District. There are number of small occurrences in Anantapur, Khammam, Krishna, Kurnoool, Mahaboobnagar, Nellore and Prakasam districts. All most all the deposits of barites occur in association with minor quartz and calcite in fissures and joint planes in traps, dolomite and quartzite. At present mineral is mostly mined by opencast, the vein type deposits are being mined along the strike and dip of the vein. The material excavated is sorted at the surface into different grades based on the colour. The barites brought from mangampet, kapada are used as coarse aggregate in this project.

\subsection{Silica Fume}

Silica fume is a by-product in the production of silicon and ferrosilicon alloys. It is ultrafine material with spherical particles less than 1 micro meter in diameter, the average being about 0.15 micro meter.which protects the reinforcing steel of concrete from corrosion, especially in chloride rich environments such as coastal regions and those of humid continental roadways, runways and salt water. Silica Fume reduces the bleeding. 
Table 1

\begin{tabular}{|l|l|l|}
\hline S.NO & Property & Test Results \\
\hline 1 & Normal Consistency & $32 \%$ \\
\hline 2 & Specific Gravity & 3.2 \\
\hline 3 & Initial and Final setting time & $\begin{array}{l}115 \mathrm{~min} \& 542 \\
\mathrm{~min}\end{array}$ \\
\hline 4 & Soundness value & $2 \mathrm{~mm}$ \\
\hline 5 & $\begin{array}{l}\text { Fineness of cement(Dry } \\
\text { sieving method) }\end{array}$ & $5 \%$ \\
\hline
\end{tabular}

Properties of Silica Fume

\section{LITERATURE REVIEW}

(i) Ahmed S.Ouda(2014)on Development of heavy density using different aggregates for gamma rays shieldingand published a paper in international journal on 19 June 2014. A high

(ii) Sh.Sharifi, R.Bhageri and S.P. Shirmardi Department of civil engineering, Islamic Azad University, Iraq published a paper in ELSEVIER journal, 8 sep 2012 on comparision of shielding properties for ordinary, barite, serpentine and steel-magnetite concretes.

\section{THEORITICAL ANALYSIS}

\subsection{Cement}

ordinary Portland cement53 grade of cement is used in this investigation

Physical properties of OPC 53 grade are as follows.
Table 2

\begin{tabular}{|l|l|l|}
\hline $\begin{array}{l}\text { S.N } \\
\text { O }\end{array}$ & Property & Test Results \\
\hline 1 & Normal Consistency & $32 \%$ \\
\hline 2 & Specific Gravity & 3.1 \\
\hline 3 & Initial and Final setting time & $\begin{array}{l}115 \mathrm{~min} \& 542 \\
\mathrm{~min}\end{array}$ \\
\hline 4 & Soundness value & $2 \mathrm{~mm}$ \\
\hline 5 & $\begin{array}{l}\text { Fineness of cement(Dry sieving } \\
\text { method) }\end{array}$ & $5 \%$ \\
\hline
\end{tabular}

\section{Properties of OPC}

\subsection{Fine Aggregate}

Aggregates smaller than $4.75 \mathrm{~mm}$ and upto $0.075 \mathrm{~mm}$ are considered as a fine aggregate. properties of Fine aggregate are as follows

Table 3

\begin{tabular}{|l|l|l|}
\hline S.NO & \multicolumn{1}{|c|}{ Property } & $\begin{array}{l}\text { Test } \\
\text { Results }\end{array}$ \\
\hline 1 & Specific Gravity & 2.6 \\
\hline 2 & $\begin{array}{l}\text { Fineness modulus of fine } \\
\text { aggregate }\end{array}$ & 2.66 \\
\hline
\end{tabular}

\subsection{SIEVE ANALYSIS OF FINE AGGREGATE:}

Weight of sample taken $1 \mathrm{~kg}$

Sieve analysis of fine aggregate is shown in Table 3

Table 3

\begin{tabular}{|l|c|c|c|c|l|}
\hline $\begin{array}{l}\text { Sieve size } \\
\text { In mm }\end{array}$ & $\begin{array}{l}\text { Wt. retained } \\
\text { In grams }\end{array}$ & $\begin{array}{l}\text { Cumulative } \\
\text { Wt. retained } \\
\text { In gms }\end{array}$ & $\begin{array}{l}\text { \% of cumulative } \\
\text { Wt. retained }\end{array}$ & $\begin{array}{l}\text { \% of cumulative } \\
\text { Wt. passing }\end{array}$ & Zone \\
\hline 4.75 & 26 & 26 & 2.6 & 97.4 & $90-100$ \\
\hline 2.36 & 29 & 55 & 5.5 & 94.5 & $75-100$ \\
\hline 1.18 & 130 & 185 & 18.5 & 81.5 & $55-90$ \\
\hline 0.6 & 306 & 491 & 49.1 & 50.9 & $35-59$ \\
\hline 0.3 & 414 & 905 & 90.5 & 9.5 & $8-30$ \\
\hline 0.15 & 91 & 996 & 99.6 & 0.4 & $0-10$ \\
\hline
\end{tabular}

Sieve Analysis of Fine Aggregate

\section{Observations:}

Fineness modulus of the fine aggregate is $=$ sum of \%cumulative retained

$=\frac{266.1}{100}=2.66$

\section{COARSE AgGREgATE}

The aggregates greater than $4.75 \mathrm{~mm}$ are considered as a coarse aggregate.
Physical properties of coarse aggregate are as follows.

Table 4

\begin{tabular}{|l|l|c|}
\hline S.NO & Property & Test Results \\
\hline 1 & Specific Gravity & 2.83 \\
\hline 2 & Aggregate Impact Test & $15.3 \%$ \\
\hline 3 & Aggregate Crushing Test & $13.3 \%$ \\
\hline 4 & Shape Tests & \\
& a) Flakiness Test & $42.18 \%$ \\
& b) Elongation Test & $22.5 \%$ \\
\hline
\end{tabular}

Physical properties of coarse aggregate 


\subsection{Barites}

Physical Properties of Barites Are As Follows.

Table 5

\begin{tabular}{|l|l|c|}
\hline S.NO & Property & Test Results \\
\hline 1 & Specific Gravity & 4.2 \\
\hline 2 & Aggregate Impact Test & $44.2 \%$ \\
\hline 3 & Aggregate Crushing Test & $62 \%$ \\
\hline
\end{tabular}

3.6 Mix Design For M25 Grade (As Per Is 10262:2009)

The Following Specifications Were Considered For Mix Design

(i) characteristic compressive strength required in the field at 28 days : $25 \mathrm{~N} / \mathrm{mm}^{2}$ (ii) maximum size of aggregate

$20 \mathrm{~mm}$

(iii) degree of quality control

good

(iv) type of exposure

: mild

Select the w/c ratio from table.no. 2 of IS 456:2000 $\mathrm{w} / \mathrm{c}=0.5$

From the table 3 of IS $\mathbf{4 5 6}$ for the maximum aggregate size $20 \mathrm{~mm}$ Water content $=186 \mathrm{~kg} / \mathrm{m}^{3}$

Cement content $=372 \mathrm{~kg} / \mathrm{m}^{3}$

Mass of coarse aggregate $=1218 \mathrm{~kg}$

Mass of fine aggregate $=686 \mathrm{~kg}$

Mix proportion=1:1.84:3.27 for water cement ratio 0.5 .

\section{Mix Proportions}

Table 6

\begin{tabular}{|c|c|c|c|c|c|c|c|c|c|}
\hline \multirow{3}{*}{$\begin{array}{l}\text { Grade of } \\
\text { Concrete }\end{array}$} & \multirow{3}{*}{$\begin{array}{c}\% \text { BRT+ } \\
\% \text { SF }\end{array}$} & \multirow{2}{*}{\multicolumn{2}{|c|}{ Binding Material }} & \multirow[t]{3}{*}{ Fine Aggregate } & \multicolumn{4}{|c|}{ Coarse aggregates } & \multirow{2}{*}{$\begin{array}{l}\text { W/C } \\
\text { Ratio }\end{array}$} \\
\hline & & & & & \multicolumn{2}{|c|}{ Coarse Aggregate $\left(\mathrm{kg} / \mathrm{m}^{3}\right)$} & \multicolumn{2}{|c|}{ BRT } & \\
\hline & & Cement & SF & & $20 \mathrm{~mm}$ & $10 \mathrm{~mm}$ & $20 \mathrm{~mm}$ & $10 \mathrm{~mm}$ & \\
\hline M25 & $0+4$ & 372 & 0 & 686 & 730 & 487 & 0 & 0 & 0.5 \\
\hline M25 & $25+4$ & 357 & 15 & 686 & 548 & 365 & 183 & 122 & 0.5 \\
\hline M25 & $50+4$ & 357 & 15 & 686 & 365 & 244 & 365 & 244 & 0.5 \\
\hline
\end{tabular}

\section{RESULTS AND DISCUSSION}

\subsection{Tests For Workability}

The results on tests for are shown in table Workability

Slump and compaction factor valus for M25
Table 7

\begin{tabular}{|c|c|c|c|}
\hline Sl No. & MIX & Slump & $\begin{array}{c}\text { Compaction } \\
\text { Factor }\end{array}$ \\
\hline 1. & Normal concrete & 85 & 0.88 \\
\hline 2. & $25 \%$ BRT & 75 & 0.89 \\
\hline 3. & $50 \%$ BRT & 70 & 0.92 \\
\hline
\end{tabular}

\subsection{Test For Anti-Radiation of Concrete}

Anti radiation results are shown in Table 8.

Table 8

\begin{tabular}{|c|c|c|c|}
\hline Particulars & Distance & Radiation absorbed & Radiation emitted \\
\hline 3 days : Normal concrete & $2000 \mathrm{~mm}$ & $108.0 \mathrm{mR}$ & $12.0 \mathrm{mR}$ \\
\hline $25 \%$ BRT & $2000 \mathrm{~mm}$ & $108.5 \mathrm{mR}$ & $11.5 \mathrm{mR}$ \\
\hline $50 \%$ BRT & $2000 \mathrm{~mm}$ & $110.0 \mathrm{mR}$ & $10.0 \mathrm{mR}$ \\
\hline 7 days : Normal concrete & $2000 \mathrm{~mm}$ & $108.0 \mathrm{mR}$ & $12.0 \mathrm{mR}$ \\
\hline $25 \%$ BRT & $2000 \mathrm{~mm}$ & $109.0 \mathrm{mR}$ & $11.0 \mathrm{mR}$ \\
\hline $50 \%$ BRT & $2000 \mathrm{~mm}$ & $110.0 \mathrm{mR}$ & $10.0 \mathrm{mR}$ \\
\hline 28 days : Normal concrete & $2000 \mathrm{~mm}$ & $108.0 \mathrm{mR}$ & $12.0 \mathrm{mR}$ \\
\hline $25 \%$ BRT & $2000 \mathrm{~mm}$ & $109.0 \mathrm{mR}$ & $11.0 \mathrm{mR}$ \\
\hline $50 \%$ BRT & $2000 \mathrm{~mm}$ & $110.0 \mathrm{mR}$ & $10.0 \mathrm{mR}$ \\
\hline
\end{tabular}




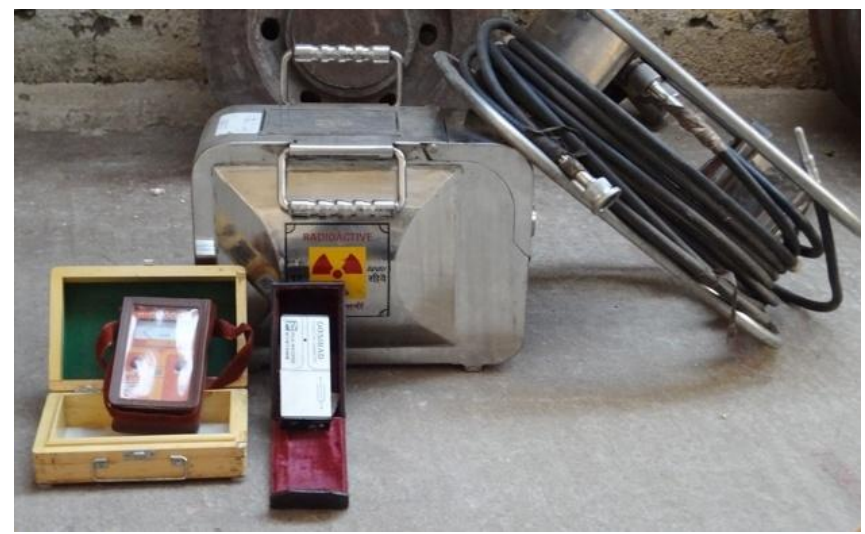

\subsection{Compressive Strength of Concrete}

CTM OF $2000 \mathrm{kN}$ capacity was used with load rate of approximately $140 \mathrm{~kg} / \mathrm{cm} / \mathrm{min}$ until failure for compressive strength test.Test results for compressive strength are presented in Table 10

various mixes used in this investigation are shown in table 9

Fig.1 Source of radiation

Table 9

\begin{tabular}{|c|c|c|c|c|c|c|c|}
\hline \multirow{3}{*}{$\begin{array}{c}\text { Constituents of Concrete } \\
\text { Mix Types }\end{array}$} & \multirow{2}{*}{ Binding Material } & \multirow{2}{*}{\multicolumn{2}{|c|}{$\begin{array}{c}\text { Fine Aggregate } \\
\text { Sand }\end{array}$}} & \multicolumn{4}{|c|}{ Coarse Aggregates } \\
\hline & & & & \multicolumn{2}{|c|}{ Coarse Aggregate } & \multicolumn{2}{|c|}{ Barites } \\
\hline & Cement & SF & & $20 \mathrm{~mm}$ & $10 \mathrm{~mm}$ & $20 \mathrm{~mm}$ & $10 \mathrm{~mm}$ \\
\hline Normal mix & $100 \%$ & $4 \%$ & $100 \%$ & $60 \%$ & $40 \%$ & $0 \%$ & $0 \%$ \\
\hline $25 \%$ BRT $+4 \%$ SF & $96 \%$ & $4 \%$ & $100 \%$ & $45 \%$ & $30 \%$ & $15 \%$ & $10 \%$ \\
\hline $50 \% \mathrm{BRT}+4 \% \mathrm{SF}$ & $96 \%$ & $4 \%$ & $100 \%$ & $30 \%$ & $20 \%$ & $30 \%$ & $20 \%$ \\
\hline
\end{tabular}

Compressive strength values for replacement of coarse aggregate with barites and cement

Table 10

\begin{tabular}{|c|c|c|c|c|}
\hline \% BRT & \% SF & 3 days & 7 days & 28 days \\
\hline 0 & 4 & 27.4 & 30.9 & 40.8 \\
\hline 25 & 4 & 21.78 & 29.05 & 37.46 \\
\hline 50 & 4 & 23.62 & 30.21 & 33.51 \\
\hline
\end{tabular}

\section{DISCUSS ON RESULTS}

\subsection{Normal Concrete}

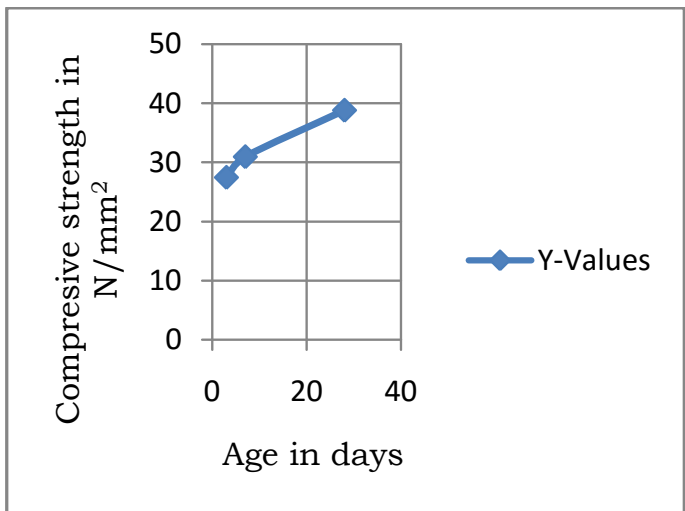

Fig.2 Graph showing compressive strength of Concrete for Normal concrete

\subsection{Effect of variation of Barites on compressive}

\section{strength}

The compressive strength of concrete for 3days,7days and 28days for $25 \%$ and $50 \%$ replacement of Barites and the values are presented in fig. 3 and fig. 4
$25 \%$ BRT concret

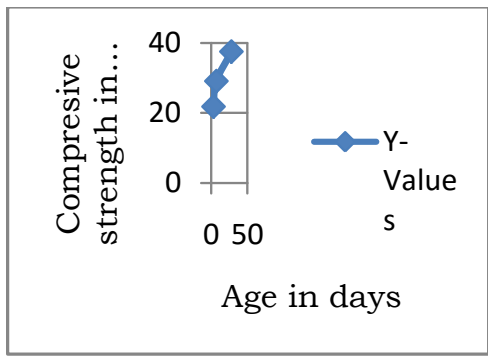

Fig.3 Graph showing for 25\%BRT compressive strength of Concrete

50\% BRT concrete:

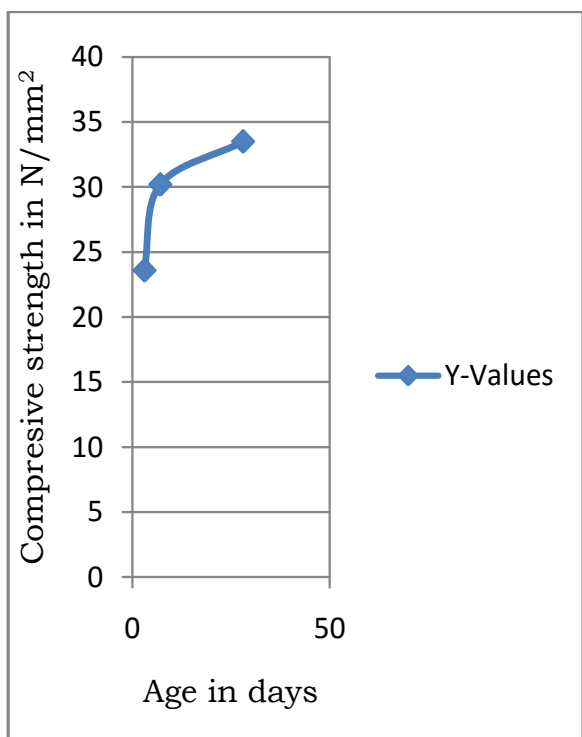

Fig.4 Graph showing compressive strength of Concrete for $50 \%$ BRT 


\subsection{Effect of Radiation of Shielding of Concrete}

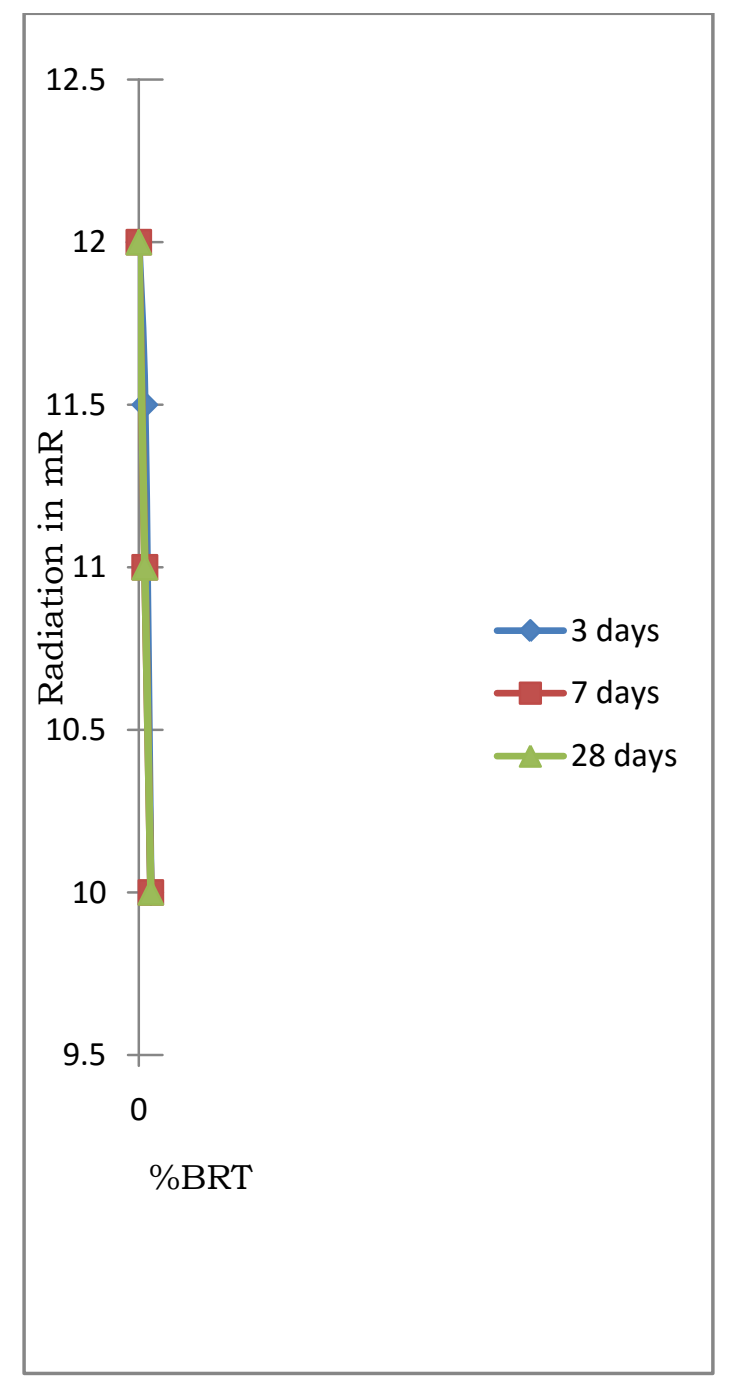

Fig.5 Graph showing emitted radiation for various proportions of barites.

This study was carried out to obtain the results, tests conducted on Barites and Silica fume modified cement concrete mix, in order to ascertain the influence ofbarites on the characteristics strength of concrete and Anti radiation of concrete.

The variation of compressive strength of concrete mix with different proportion of barites as partial re-placement of coarse aggregate and Anti radiation of concrete with variation in percentage of barites.

From the above results it can be observed that:

1. Anti-radiation concrete is almost 1.5 times heavier and denser than the ordinary cement and this is the reason that heavy concrete has better absorbing properties than normal cement.

2. The Compressive strength of the high density concrete gives the same level of compressive strength of normal concrete.

3. The shielding of concrete increasing with increase in percentage of barites.

\section{CONCLUSIONS}

Based on analysis of experimental results and discussion there upon following conclusion can be drawn

1. The partial replacement of Barites balances the requirementsfor strength and radiation shielding.

2. The results showed that the replacement of $50 \%$ barites shown the better shielding properties than $25 \%$ barites.

3. Silicafume has a significant effect on reducing the thickness required for shielding, compared with mixesof the same proportions without silicafume.

4. The Compressive strength of $25 \%$ replacement barites exhibits the same level of compressive strength of normal concrete

Hence by all the above statements partial replacement of coarse aggregate with Barites and the cement with Silica fume had given better shielding properties compared to plain concrete and exhibits the same level of compressive strength of normal concrete.

\section{REFERENCES}

[1] IS: 383 (1970). Indian Standard Specification for Coarse and Fine aggregates from Natural Sources for Concrete (Second Revision). Bureau of Indian Standards, New Delhi.

[2] IS: 456 (2000). Indian Standard Plain and Reinforced Concrete Code of Practice. Bureau of Indian Standards, New Delhi.

[3] IS: 10262 (2009). Recommended Guidelines for Concrete Mix Design. Bureau of Indian standards, New Delhi.

[4] Shetty M.S, "Concrete Technology" (theory and practice), S. Chand Publications-1982.

[5] Ahmed Ouda .S, (2014) "Development of heavy density using different aggregates for gamma rays shielding"HRBC international journal ISSN 2319 6009 Vol. 3, No. 2.

[6] Sagar Singh. B and Ramana K. V (2014) "Mechanical properties of heavy weight concrete using heavy weight coarse aggregate as hematite" International Journal of Research in Engineering and Technology volume 3: issue9.

[7] Sharifi .Sh ,Bhageri. R and Shirmardi S. P (2012) "comparison of shielding properties for ordinary, barite, serpentine and steel-magnetite concretes" ELSEVIER journal,14155-1339. 